\title{
Knowledge and Practice of Health Care Workers regarding Needle Stick Injuries in a Tertiary Care Center of Nepal
}

\section{Singh $B,{ }^{1}$ Paudel $B,{ }^{1} K C S^{2}$}

\author{
Corresponding Author \\ Bishnu Singh \\ Department of Nursing \\ Dhulikhel Hospital, Kathmandu University Hospital \\ Dhulikhel, Kavre, Nepal. \\ E-mail: bishnu.singh@yahoo.com
}

\section{Citation}

Singh B, Paudel B, KC S. Knowledge and Practice of Health Care Workers regarding Needle Stick Injuries in a Tertiary Care Center of Nepal. Kathmandu Univ Med J 2015;51(3):230-3.

\section{ABSTRACT}

\section{Background}

Needle stick injuries are common health hazards among health care workers. Considering the increasing prevalence of body fluid borne infectious diseases; knowledge regarding the common errors and universal precautions are vital for the prevention of such accidents.

\section{Objective}

This study aimed to assess for knowledge and practice approaches among health care workers regarding needle stick injuries.

\section{Method}

This is a cross sectional survey was conducted using an anonymous, self-reporting 25 -item structured questionnaire at a tertiary care center of central Nepal. A total of 165 health care personnel of working experience of more than 6 months were included in the study. Questionnaire included aspects of prevalence and knowledge on needle stick injury, hepatitis B immunization status and post exposure prophylaxis for HIV.

Result

Prevalence of needle stick injury was found to be 703 per 1000 health care worker (70.3\%) during their working tenure and majority of the injury happened among nurses $(p<0.05)$ besides other professions. Seventy nine $(47.9 \%)$ participants experienced the injury more than one time in their career and the mean number of injury was $2.06 \pm 1.16$. The practice of needle recapping is still prevalent and $80 \%$ participants often use single handed technique. Vaccination against hepatitis $B$ virus was not completed by $31 \%$ health workers. Inadequate knowledge about post exposure prophylaxis for HIV was reported by $46 \%$ participants.

\section{Conclusion}

High prevalence of needle stick injury with a high rate of ignorance was noted. These issues need to be addressed, through appropriate education and interventional strategies.

\section{KEY WORDS}

Needle stick injury, post exposure prophylaxis. 


\section{INTRODUCTION}

Needle stick injuries (NSI) are one of the common health hazards among health care workers (HCWs). It not only carries a risk of transmission of blood borne pathogens but also symbolizes quality health care services. Three diseases - hepatitis B, hepatitis C, and HIV/AIDS are of greatest concern because of their morbidity, complications or death. ${ }^{1}$ The risk of injury depends on two basic factors; the number of infectious patients and the universal precautions taken by the health care worker. Considering every patient to be infectious and following the universal discipline during handling of sharps remains to be the gold standard for the prevention of needle stick injuries.

Most of the NSI happen during recapping, opening of ampoule or vial, during procedure or during disposal of syringes. ${ }^{2}$ Various studies have shown a high prevalence of such injuries in Nepal. ${ }^{3,4}$ Further, the practice of reporting of NSI has not been well established in Nepal. Studies have shown increased prevalence of NSI among nurses besides other HCWs and injuries occur when the duties are tiresome (3 or more night duties per week or more than 36 hours duty per week). ${ }^{5}$ Introduction of safety engineered devices and safe working practices is one of the main starting points for avoidance of such injuries.

This study thus aims to assess the knowledge and practice methods of HCWs on needle stick injuries at a tertiary care center.

\section{METHODS}

This is a cross sectional survey conducted among HCWs at a tertiary care center of Nepal in August 2014. A total of $165 \mathrm{HCWs}$ from different departments of the hospital participated in this study. Total size was calculated to be 138 including $10 \%$ non-response participants. Participants were fully informed about the design and purpose of the study and a prior verbal consent was obtained. Prior ethical consent was taken from the institutional review board. Those subjects who were not frequently involved in handling sharps, working experience of less than 6 months and subjects unwilling to be included in the study were excluded from the study.

The study was carried out using a nameless, self-reporting 25-item questionnaire structured specifically to obtain predominantly quantitative data to identify extrapolative factors associated with NSIs. The questionnaire was validated by 3 experts and was pre tested among 25 similar subjects. Questionnaire contained information regarding demographic data, job category, knowledge, practices, awareness and use of preventive measures regarding NSI. Questions relating to awareness regarding preventive measures like hepatitis B immunization, use of safety devices and information on post exposure prophylaxis (PEP) were also included. Data was entered in Microsoft excel 2007 and analysis of the data was performed using statistical package for social sciences (SPSS) version 16.

\section{RESULTS}

The distribution of participants included $132(74.5 \%)$ nurses, $17(10.3 \%)$ medical officers, $12(7.3 \%)$ lab technicians and $13(7.9 \%)$ paramedic staffs (health assistants/community medical assistants). Among the nurses, 120 had proficiency certificate level degree and 12 had a bachelor degree. Among all participants $142(86.1 \%)$ were female and $23(13.9 \%)$ were male. Majority of participants $88(77.9 \%)$ were in the age group of $20-30$ years followed by $22(19.5 \%)$ in the age group of 30-40 years and 3 participants were of age 40 years and above.

Among the total 165 participants, 116(70.3\%) had history of needle stick injury in the past. The distribution of needle stick injury according to profession has been shown in fig. 1 . Further, 79(47.87\%) participants experienced it more than one time in their career. The number of injuries ranged from one to six times and the mean number of injury was 2.06 \pm 1.16 .

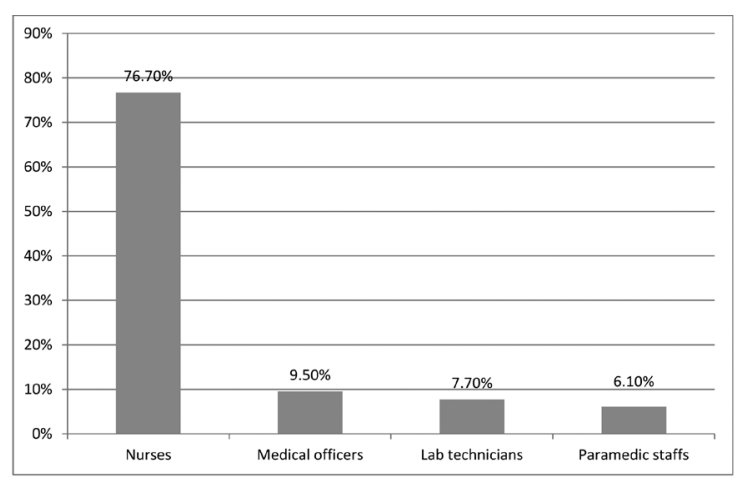

Figure 1. Distribution of needle stick injuries among various professions.

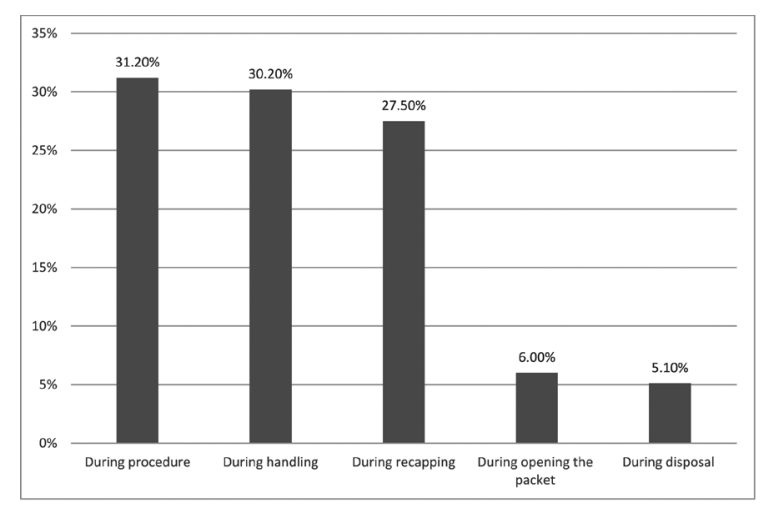

Figure 2. Period during which needle stick injury happened.

Out of 116 NSI sufferers, 49 injuries were caused by unused needles and the rest 67 were hurt by used needles. The time period during which the injury occurred is shown in fig. 2. Among the needle stick sufferers, 42(36.2\%) reported the incident but $74(63.8 \%)$ did not report the incident. The responses to various other questions have been depicted in table 1. 
Table 1. Response relating practice methods implemented before and after NSI

\begin{tabular}{|c|c|c|}
\hline S.N. & Question & Answer \\
\hline 1 & $\begin{array}{l}\text { Habit of wearing } \\
\text { gloves during mi- } \\
\text { nor procedures (eg: } \\
\text { blood drawing, can- } \\
\text { nula removal)? }\end{array}$ & $\begin{array}{l}\text { Yes }-79(68.1 \%) \\
\text { No }-37(31.9 \%)\end{array}$ \\
\hline 2 & $\begin{array}{l}\text { Action taken immedi- } \\
\text { ately after NSI }\end{array}$ & $\begin{array}{l}\text { Washed with soap / Water - 36(21.8\%) } \\
\text { Applied spirit - } 24(14.5 \%) \\
\text { Squeeze blood out - } 16(9.7 \%) \\
\text { All three - } 38(32.7 \%) \\
\text { Did nothing - } 2(1.7 \%)\end{array}$ \\
\hline 3 & Use of PEP after NSI & $\begin{array}{l}\text { Yes }-0 \\
\text { No }-116(100 \%)\end{array}$ \\
\hline 4 & $\begin{array}{l}\text { Action taken to reveal } \\
\text { patient's high risk } \\
\text { behavior (I/V drug } \\
\text { abuse, multiple sex } \\
\text { partners)? }\end{array}$ & $\begin{array}{l}\text { Yes }-2(1.7 \%) \\
\text { No }-114(98.3 \%)\end{array}$ \\
\hline 5 & $\begin{array}{l}\text { Which method of re- } \\
\text { capping do you often } \\
\text { use for recapping a } \\
\text { needle? }\end{array}$ & $\begin{array}{l}\text { Single handed technique }-132(80 \%) \\
\text { Double handed technique }-33(20 \%)\end{array}$ \\
\hline 6 & $\begin{array}{l}\text { Did you ever have a } \\
\text { mucosal contact of } \\
\text { body fluids (Blood, } \\
\text { Amniotic fluid, Urine, } \\
\text { Saliva)? }\end{array}$ & $\begin{array}{l}\text { Yes }-43(26 \%) \\
\text { No }-122(74 \%)\end{array}$ \\
\hline 7 & $\begin{array}{l}\text { How often do you } \\
\text { wear protective mask } \\
\text { and glasses during } \\
\text { procedures? }\end{array}$ & $\begin{array}{l}\text { None and never - } 9(5.5 \%) \\
\text { Only mask never glasses - } 118(71.5 \%) \\
\text { Both but not always- } 23(13.9 \%) \\
\text { Always - 15(9.1\%) }\end{array}$ \\
\hline
\end{tabular}

Responses to general questions asked to all 165 participants regarding the knowledge and practice towards NSI, Hepatitis B immunization and PEP have been shown in table 2.

Table 2. Response regarding knowledge towards PEP and Hepatitis B immunization

\begin{tabular}{|c|c|c|}
\hline S.N. & Question & Answer \\
\hline \multirow{2}{*}{1} & \multirow{2}{*}{$\begin{array}{l}\text { Do you know about Post-Expo- } \\
\text { sure Prophylaxis (PEP) for HIV? }\end{array}$} & Yes - 89(53.9\%) \\
\hline & & No - 76(46.1\%) \\
\hline \multirow{4}{*}{2} & \multirow{4}{*}{$\begin{array}{l}\text { Do you know how soon PEP is to } \\
\text { be initiated following NSI? }\end{array}$} & 2 hours $-23(14 \%)$ \\
\hline & & 24 hours - 53(32.1\%) \\
\hline & & 48 hours - 15(9\%) \\
\hline & & 5 days - 74(44.9\%) \\
\hline \multirow{4}{*}{3} & \multirow{4}{*}{$\begin{array}{l}\text { How long POST-EXPOSURE PRO- } \\
\text { PHYLAXIS is to be taken orally? }\end{array}$} & 2 weeks - 18(10.9\%) \\
\hline & & 4 weeks - 19(11.5\%) \\
\hline & & 3 months - $5(3 \%)$ \\
\hline & & Don't know - 123(74.6\%) \\
\hline \multirow{2}{*}{4} & \multirow{2}{*}{$\begin{array}{l}\text { Have you completed the dosage } \\
\text { of hepatitis B vaccination? }\end{array}$} & Yes - 114(69\%) \\
\hline & & No $-51(31 \%)$ \\
\hline
\end{tabular}

\section{DISCUSSION}

Accidental exposures from blood and body fluids have been recognized as a very common occupational hazard among health care workers. It is often very difficult to quantify the various aspects of NSI, as much of the injuries are under reported. Factors such as type and design of needle, recapping activity and method, handling or transferring specimens or sutures, cleaning activities, manipulation of needles or sutures, passing/handling devices or failure to dispose used needle in puncture proof containers have been implicated in the causation of NSI. ${ }^{1-5}$ The global estimate of such accidental exposures is nearly 3.5 million individuals. ${ }^{6}$

In our study, a very high prevalence of NSI was found (70.3\%). Nurses had the maximum needle stick injuries of $76.7 \%(p<0.05)$, constituting the largest group of HCWs which might be because of large number of nurse participants, increased work load including night shifts. Similar findings of increased prevalence and bigger distribution among nurses have been shown by various studies. $^{7,8}$ Also 79(47.87\%) participants had multiple episodes of NSI and the mean number of injuries was $2.06 \pm 1.16$. These data reflect a very high prevalence of NSI in our study. A high percentage of participants (30.2\%) had injury while handling sutures which might be because of manual handling of sutures. Lack of knowledge, longer night shifts and ignorance (eg: not wearing gloves (31.9\%)), recapping of needles, recapping using a single handed technique ( $80 \%$ ) could be its major reasons. Wearing gloves during any procedure is considered to be an important line of defense. The practice of not wearing gloves was found to be higher among nurses and laboratory technicians during NSIs. ${ }^{2}$ Similarly, recapping has been established to be a definite cause of NSI. Avoiding recapping of needles as far as possible for disposal has been a prime emphasis in modern medical practice. ${ }^{1,8-11}$ Safety engineered needles and devices having features such as shields or retractable needles have proven efficacy for the prevention of these injuries. However inaccessibility and under use of such devices in the setting of Nepal may be a major contributing factor for NSI.

It is alarming to note that majority of the participants had no proper knowledge regarding the use of PEP for HIV infection following NSI. HIV post exposure prophylaxis is an established form of secondary HIV prevention that may reduce the incidence of HIV infections following exposure. ${ }^{12,13}$ Although there is no direct evidence for its efficacy the combination multi drug therapy is believed for its success in treating HIV-infected individuals. All HCWs must be counselled that the drugs are not $100 \%$ effective in preventing HIV seroconversion. The drugs have to be started within 2 hours or as soon as possible and should be taken for total 4 weeks. It has to be made readily available for all in every hospital. In the present study it was also seen that some of the HCWs had not completed the doses 
of hepatitis B immunization. Mandatory completion of the schedule before entry into the hospital or health studies could easily eliminate such gaps.

\section{Limitations}

A single center, descriptive study involving limited sample size; are some of the limitation of the present study.

\section{REFERENCES}

1. Zanni GR, Wick JY. Preventing needlestick injuries. Consult Pharm. 2007; 22(5):400-2.

2. Sharma R, Rasania SK, Verma A, Singh S. Study of Prevalence and Response to Needle Stick Injuries among Health Care Workers in a Tertiary Care Hospital in Delhi, India. Indian J Community Med. 2010 35(1):74-7.

3. Gurubacharya DL, Mathura KC, Karki DB. Knowledge, attitude and practices among health care workers on needle-stick injuries. Kathmandu Univ Med J. 2003; 1(2):91-4.

4. Bhattarai S, KC S, Pradhan PM, Lama S, Rijal S. Hepatitis B vaccination status and Needle-stick and Sharps-related Injuries among medical school students in Nepal: a cross-sectional study. BMC Res Notes. 2014; $7: 774$

5. Narantuya G, Tsolmon M. Needle stick and sharp injuries in health care workers in Ulaanbaatar. Available at: http://www.biomedcentral. com/1753-6561/5/S6/P226. Accessed: January 2015.

6. Prüss-Ustün A, Rapiti E, Hutin Y. Estimation of the global burden of disease attributable to contaminated sharps injuries among healthcareworkers. Am J Ind Med. 2005; 48(6):482-90.

7. Mehta A, Rodrigues C, Ghag S, Bavi P, Shenai S, Dastur F. Needlestick injuries in a tertiary care centre in Mumbai, India. J Hosp Infect. 2005; 60(4):368-73.

\section{CONCLUSION}

The present study shows high prevalence of needle stick injury with a high rate of ignorance among HCWs. Respecting the golden rule of universal precautions and introduction of safety engineered needles could aid in the drop of NSI incidence. A multicenter study involving HCW and nursing staffs could highlight the broader prevalence of NSI. The need of educational programs for needle stick injury and role of post exposure prophylaxis have been felt crucial.

8. Ilhan MN, Durukan E, Aras E, Türkçüoğlu S, Aygün R. Long working hours increase the risk of sharp and needlestick injury in nurses: The need for new policy implication. J Adv Nurs. 2006; 56:563-8.

9. Kermode M, Jolley D, Langkham B, Thomas MS, Crofts N. Occupational exposure to blood and risk of bloodborne virus infection among health care workers in rural north Indian health care settings. Am J Infect control. 2005; 33(1):34-41.

10. Ebrahimi $\mathrm{H}$, Khosravi $\mathrm{A}$. Needlestick injuries among nurses. J Res Health Sci. 2007; 7(2):56-62.

11. Lavoie MC, Verbeek JH, Pahwa M. Devices for preventing percutaneous exposure injuries caused by needles in healthcare personnel. Cochrane Database Syst Rev. 2014 Mar 9; 3:CD009740.

12. Merchant RC, Keshavarz R. Human immunodeficiency virus postexposure prophylaxis for adolescents and children. Pediatrics. 2001; 108(2):E38.

13. Young TN, Arens FJ, Kennedy GE, Laurie JW, Rutherford GW. Antiretroviral post-exposure prophylaxis (PEP) for occupational HIV exposure. Cochrane Database Syst Rev. 2007 Jan 24; 1: CD002835. 